\title{
New data on facies development and micropaleontology of the eastern margin of the Getic Carbonate Platform (South Carpathians, Romania): case study of the Mateiaş Limestone
}

\author{
Ioan I. BUCUR ${ }^{1}$, Daniela BELEŞ ${ }^{2}$, Emanoil SĂSĂRAN ${ }^{1}$ \& Constantin BALICA ${ }^{1}$ \\ ${ }^{1}$ Department of Geology, Babeş-Bolyai University, Kogălniceanu 1, 400084 Cluj-Napoca, Romania. \\ ${ }^{2}$ Holcim S.A., Calea Floreasca 169A, Building B, Suites 7-8, 014459 Bucharest 1, Romania.
}

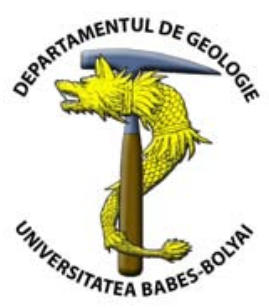

ABSTRACT. The Mateiaş Limestone is a lithostratigraphic unit in the Braşov Series, a component of the eastern part of the Getic Nappes' cover (the Getic carbonate platform). Four main facies and their associated microfacies are identified in the Mateiaş Limestone in the Hulei-Mateiaş-Măgura area. A Kimmeridgian (possibly also Early Tithonian) age is assigned to the Mateiaş Limestone, based on the microfossil association identified in thin sections. The regional setting, as well as sedimentological and micropaleontological features, indicates deposition of these limestones in shelf margin and slope environments. The succession in the area studied corresponds to the lower-mid part of the carbonate succession developed in the more internal part of the eastern sector of the Getic carbonate platform (e.g. Piatra Craiului Mountains).

Key words: Facies-microfacies, microfossils, Upper Jurassic, South Carpathians, Romania.

\section{INTRODUCTION}

During the Late Jurassic-Early Cretaceous a large part of the Getic domain (the Getic nappe - a component of the median Dacides according to Săndulescu, 1984) consisted of shallow-water carbonate deposits (the Getic carbonate platform). In the Southern Carpathians, these deposits crop out extensively, from the Căvăran-Rusca Montană area in the west to the Dâmbovicioara area in the east. The southeastern end of the Upper Jurassic Getic carbonate platform is present in outcrops in the vicinity of Câmpulung Muscel, within and to the south of Mateiaş Hill. The aim of this study is to clarify some aspects of the facies evolution of the Mateiaş Limestone. These data could provide the basis for a subsequent detailed reconstruction of the sedimentary evolution of the entire Getic platform during the Late Jurassic.

\section{LOCATION AND GEOLOGICAL SETTING}

The area under study is located north-east of Câmpulung Muşcel town, close to Valea Mare-Pravăț. Geographically it is in the south-eastern part of the Southern Carpathians, near their limit with the Getic Subcarpathians (Fig. 1).

Geologically, the Jurassic limestone massif extending from the Măgura-Mateiaş-Hulei area in the north to the Piatra-Stoieneşti area in the south belongs to the eastern part of the Getic Nappe cover, and constitutes part of the Getic carbonate platform, including the limestones of the Piatra Craiului Massif and the Dâmbovicioara Gorges. The Getic carbonate platform developed during the Late Jurassic and *Correspondence: I.I. Bucur (ioan.bucur@ubbcluj.ro)
Early Cretaceous on older sedimentary deposits, or on the crystalline basement, of the area now corresponding to the Southern Carpathians. It belongs to the Median Dacides (Săndulescu, 1984) or to the sedimentary cover of the Getic craton (Balintoni, 1997).

Patrulius (1969) recognized that the formations developed along the border of Leaota Massif can be assigned to three facies zones: 1) Dâmbovicioara; 2) Pre-Leaota and 3) Sinaia Beds. The first two ones represent the cover of the external part of the Getic unit. The formations of the Dâmbovicioara zone constitute the Braşov Series, including Triassic, Jurassic and Lower Cretaceous deposits.

The limestones from the Mateiaş-Hulei area have been studied by Popescu-Voiteşti (1909), Patrulius et al. (1968), Patrulius (1969) and Ştefănescu and Ştefănescu (1985). The latter defined the Mateiaş Limestone as a distinctive lithostratigraphic unit and provided a detailed description of the carbonate deposits in the area. According to Ştefănescu and Ştefănescu (1985), the Mateiaş Limestone represent a dominantly bioconstructed deposit of KimmeridgianTithonian age that may be separated into three divisions from base to top, designated $\alpha, \beta$, and $\gamma$.

In general, the $\alpha$ division consists of massive limestones dominated by coral colonies, algae, bryozoans, gastropods and locally brachiopods. In the Hulei-Mateiaş area, reef breccias have a white micritic matrix and elements of bioconstructed limestones. The thickness ranges from more than $300 \mathrm{~m}$ in the Hulei-Mateiaş area to about $30 \mathrm{~m}$ in the Piatra area, the deposits completely disappearing towards the south (Stoeneşti). The $\beta$ division is represented by wellstratified $(5-25 \mathrm{~cm}$ beds) biosparitic and pelsparitic 
limestones. One distinctive feature is the presence of irregular, yellowish-brownish silica nodules. Ştefănescu and Ştefănescu (1985) consider that the silica nodules formed after deposition of the limestones; their contours show no relationship with the structure of the limestones or the organic components. In places the silica nodules are grouped into two distinctive levels (at the base and top of $\beta$ unit), delimiting a 15-19 m-thick layer of less-stratified limestones that lack siliceous nodules. The overall thickness of the $\beta$ division ranges from 20-40 m. Division $\gamma$ consists of micritic or sparitic limestones. In some of the sections, a gradual transition from unit $\beta$ to unit $\gamma$ is noticeable. In places division $\gamma$ commences with a well-stratified horizon, locally showing mud-mounds morphologies. In certain areas, tree-like corals have been identified. The total thickness of $\gamma$ unit is thought to exceed $100 \mathrm{~m}$ (to the west of Mateiaş).

Ştefănescu and Ştefănescu (1985) assigned a Kimmeridgian-Tithonian age to the Mateiaş Limestone based mainly on the micropaleontological evidence provided by Clypeina jurassica (Favre) and Macroporella pygmaea (Guembel) respectively Clypeina sulcata (Alth) and Salpingoporella pygmaea (Guembel).

The carbonates of the Mateiaş area are stratigraphically overlain by Upper Cretaceous deposits (starting with Vraconian-Cenomanian conglomerates and sandstones). They are in turn succeeded by Cenozoic (Oligocene-Lower Miocene) deposits. The main geological divisions discussed by Ştefănescu and Ştefănescu (1985) are also represented on the 1:50.000 geological map, Câmpulung Muscel sheet (Ştefănescu et al., 1983), that shows both the stratigraphic succession and the main tectonic elements present in the Mateiaş Limestone outcrop area.

As already mentioned, our study deals only with the area of the Hulei and Mateiaş hills, and provides new microfacies, micropaleontological and sedimentological information.

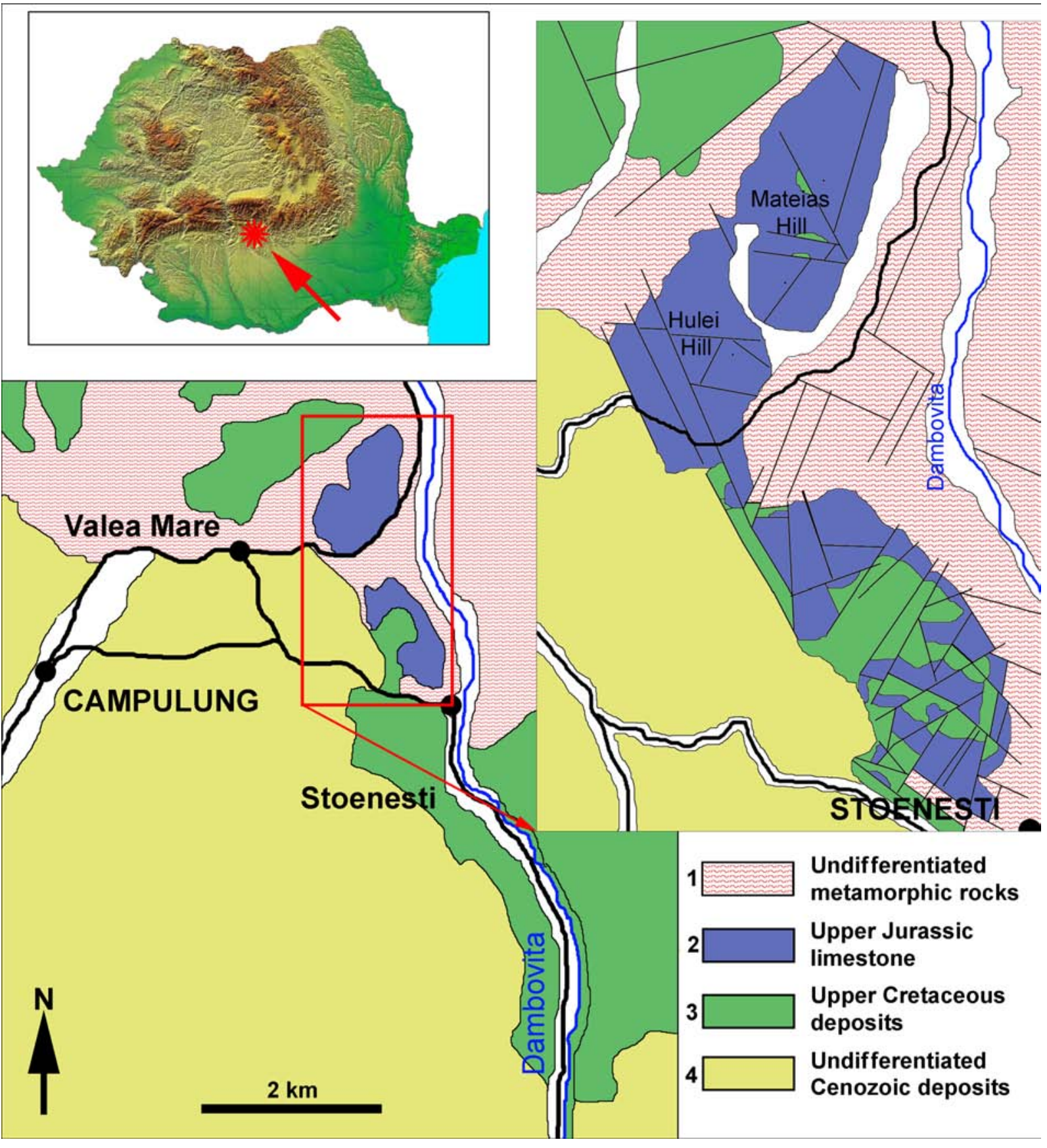

Fig. 1. Location of the study area (modified from the 1:50.000 geological map, Câmpulung Muscel Sheet; Ştefănescu et al., 1983). 


\section{FACIES AND MICROFACIES}

Mapping in the area of Hulei Quarry and MateiaşMăgura Hills revealed aspects of the facies and microfacies development of these limestones. These broadly agree with the observations of Ştefănescu and Ştefănescu (1985). Four major facies types can be distinguished (Fig. 2):
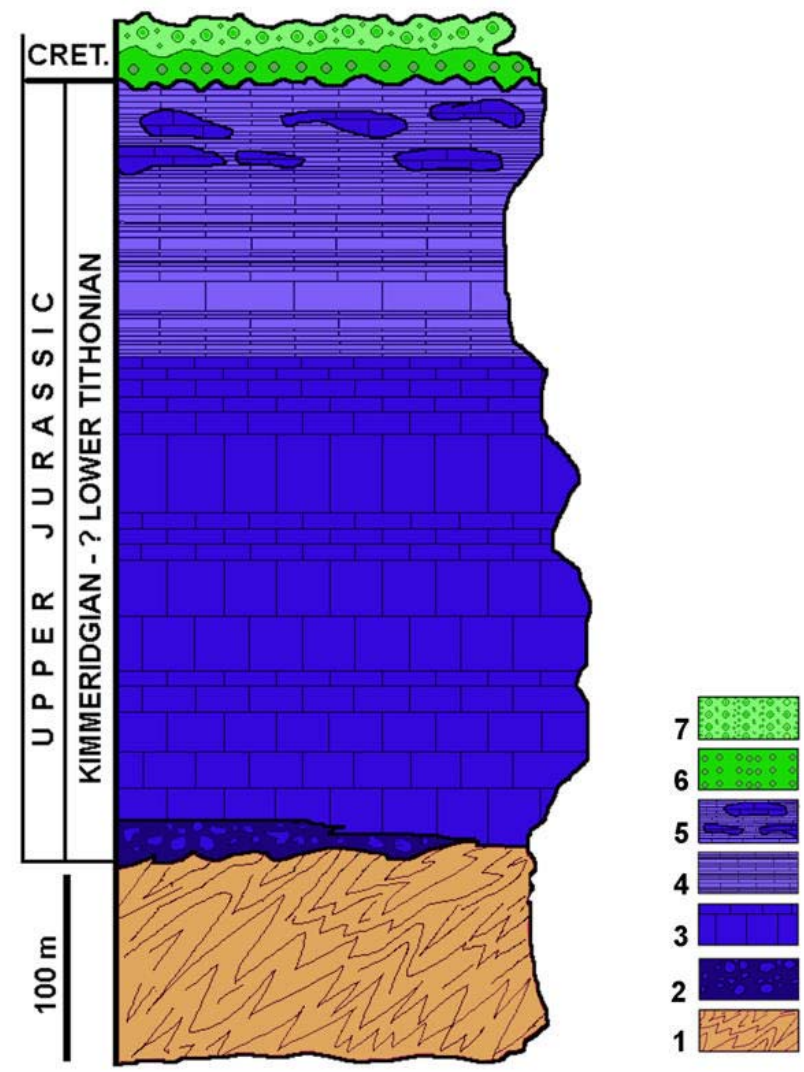

Fig. 2. Succession of the Mateiass Limestone in the HuleiMateiaş area. 1: crystalline basement; 2: carbonate basal breccias; 3: reefal limestones and upper slope breccias; 4: turbiditic limestones; 5: turbiditic limestones with reworked reefal blocks; 6: Cretaceous carbonate conglomerates; 7: Cretaceous siliciclastic conglomerates.

(Facies A) Reef limestones, forming massive deposits in outcrop, frequently with corals (Pl. I, Fig. 1). Microbialites were important in the development of these limestones, and they can be considered as coral-microbialite boundstone. Coral limestones proper are relatively rare and cover small areas, corals being noticeable on weathering surfaces (Pl. 1, Fig. 1). Thin sections show that the corals are closely associated with various types of crust (Pl. I, Figs. 3-5) and microbial structures, most commonly stromatolites (laminated) and thrombolites (clotted). Among the encrusting organisms associated with the coral-microbialitic boundstones, the most frequently identified were (Pl. I, Fig. 2) Crescentiella morronensis, Radiomura cautica, and Koskinobulina socialis. Worm tubes (annelids and Mercierella dacica) are also common.

In the western parts of the study area, blocks of reef limestones are embedded in thin-bedded limestones. Their sizes range from 1-100s of $\mathrm{m}^{3}$. They include both sparitic and micritic limestone, as described by Ştefănescu and Ştefănescu (1985).

(Facies B) Fore-reef breccias, or reef rudstone, which occur as thick banks in outcrop (Pl. I, Fig. 6). Together with the coral-microbial reefs, these deposits represent the main lithological unit cropping out in Hulei-Mateiaş area.

The main microfacies is a bioclastic-intraclastic rudstone. Rudstones are more abundant than boundstones in Hulei quarry and Mateiaş Hill. The coarse fraction is mainly composed of corals and/or microbialite fragments. Intraclasts of allodapic grainstone, packstone, and calcareous breccias are also locally present. In most cases, the matrix is medium to fine-graned grainstone, frequently including fragments of sclerosponges, corals, bivalves, gastropods, brachiopods, bryozoans, crab shells (Carpathocancer), worm tubes, echinoderms (the latter being the most abundant), dasycladalean algae and benthic, mainly agglutinated, foraminifers (Pl. I, Fig. 7). Encrusting organisms (Crescentiella morronensis, Radiomura cautica, Koskinobulina socialis) are also present.

(Facies C) Bedded limestones, in centimetre to metrethick layers (Pl. I, Fig. 6), are mainly bioclastic, most probably representing grain flows. The sedimentary bodies show sheet-like geometries, and extend throughout the outcrop area. These deposits are interlayered with the upper part of the reef limestones, or overlie them in the succession. At the top, they are associated with finely-stratified allodapic deposits.

The microfacies is represented by bioclastic grainstone (in some cases grainstone/packstone). The main clasts are of sclerosponges, corals, bivalves, gastropods, annelid worms and echinoderms (the latter being predominant). The matrix also contains benthic foraminifers, dasycladalean algae, rivulariacean-type cyanobacteria, Crescentiella, and Terebella. Sometimes sponge spicules occur as local concentrations. Syntaxial cement overgrowths on the echinoderm plates are a frequent feature. In most of the cases, grain size sorting is obvious. Sometimes, the allodapic grainstones directly overlie coral constructions or microbial crusts (Pl. II, Fig. 1). Frequently, the base of these limestones is erosional, while their upper, fine-grained part passes gradually into micritic facies with sponge spicules.

(Facies D) Thin-bedded allodapic limestones, sometimes containing silica nodules (cherts), and often folded (Pl. II, Fig. 2). They occur at some horizons, within blocks of reef limestones or reef breccia. In general, the layers are about $10-20 \mathrm{~cm}$ thick. Some thicker beds, $>50 \mathrm{~cm}$, are present within the finely-stratified allodapic limestones in Hulei Quarry, as components of cycles. Diagenetic silica is more common in the finely-stratified beds. At Mateiaş Hill, the thin-bedded limestones are less evident, probably being tectonically laminated. The main microfacies of these depoits is fine-grained grainstone-packstone. These limestones are associated with hemipelagic deposits accumulated from suspensions. They are in centimetric layers and are mainly bioclastic mudstones and wackestones containing sponge spicules, echinoderm plates and hemipelagic foraminifers. The main feature of these deposits is their association with turbiditic deposits, and the presence of silicified intercalations.

The fine-grained grainstone-packstone (Pl. II, Fig. 3) consists of small bioclasts, especially tiny echinoderm plates and bivalves. Benthic foraminifers - generally small - are also present, including Lenticulina sp. and sponge spicules, and in most cases occur as local concentrations. Massive bedding, normal and reverse grain sorting, and complete or incomplete Bouma (1962) sequences have been observed. 
Recrystallized ooids with radial structure are also present, sometimes constituting the dominant elements of the finelystratified allodapic limestones. They occur as layers of various grain sizes, in micritic matrix or sparitic cement. Locally, allodapic limestones contain frequent diagenetic silica nodules (cherts), and gradually pass into micrites with sponge spicules (P1. II, Fig. 4).

The sedimentary structures of these deposits, and their association with hemipelagic limestones, are consistent with these deposits having formed as turbidite flows (cf. Eberli, 1991; Einsele, 1991). A common diagenetic feature of calcareous turbidites is silicification, probably penecontemporaneous with lithification (Eberli, 1991).

The thin-bedded limestones are sometimes interlayered with massive (decimetric- to metric) layers consisting either of rudstone or of coral-microbialitic boundstone. Such interlayers are present at the base, and (more frequently) at the top of the turbiditic succession.

\section{Cretaceous conglomerates and microconglomerates}

The calcareous conglomerates (Pl. II, Fig. 5) occur especially in the area of Mateiaş Hill, along fault lines. The presence of red coralline algae (Paraphyllum primaevum) and "solenoporaceans" (Parachaetetes asvapatii) support an Albian-Cenomanian age for these conglomerates.

The clasts are highly-rounded, mainly carbonate, and of very diverse origins, from shallow intertidal or subtidal limestones, boundstones and rudstones, to finely granular calcareous turbidites. Fragments of crystalline schists and quartz grains also occur. The matrix is carbonate, and silt to fine sand, and includes numerous quartz grains (Pl. II, Fig. 5).

\section{Breccias and microbreccias}

Breccias occur as irregular interlayers within the coralmicrobialitic boundstones or in rudstones (Pl. II, Fig. 6). They contain large fragments of coral or microbialite boundstone, or sometimes of grainstone-packstone. The brownish-reddish, or greyish matrix of the breccia is silt to fine-sand grade vadose carbonate sediment, with rare quartz grains. Often, the voids between the breccia fragments were first veneered by denticulate vadose cement, the siltic matrix being deposited subsequently. Most probably, these features point to a karstic origin for these breccias.

\section{THE AGE OF THE MATEIAŞ LIMESTONE}

Thin sections of the limestones from Hulei Quarry and Mateiaş Hill provide evidence of a micropaleontological association calcareous algae, benthic foraminifers, encrusting microorganisms, and calcimicrobes. Most of the calcareous algae and foraminifers were found in the reef rudstone, bioclastic grainstone, and fined-grained grainstone-packstone (Facies B, C, and part of Facies D), while encrusters and calcimicrobes are related to coral-microbial reef (Facies A).

\section{Calcareous algae}

Dasycladaleans: Clypeina sulcata (ALTH) (P1. III, Fig. 3), Clypeina sp., Griphoporella cf. cretacea DRAGASTAN, ?Linoporella sp., Petrascula bursiformis (ETTALON), Salpingoporella pygmaea (GUEMBEL) (P1. III, Figs. 1, 2), Terquemella div. sp.

Studia UBB, Geologia, 2010, 55 (2), 33 - 41
Udoteaceans: Arabicodium sp. (P1. III, Fig. 5), Halimeda misiki SCHLAGINTWEIT, DRAGASTAN \& GAWLICK (Pl. III, Fig. 4).

Thaumatoporellales: Thaumatoporella parvovesiculifera RAINERI

"Solenoporaceans": "Solenopora" sp.

\section{Foraminifers}

?Acruliammina sp., Andersenolina alpina (LEUPOLD), Andersenolina div. sp. (P1. III, Fig. 16), ?Ammobaculites sp., Charentia evoluta (GORBATCHICK) (Pl. III, Fig. 9), Coscinophragma cribrosa (REUSS) (Pl. III, Fig. 13), Everticyclammina virguliana (KOECHLIN) (P1. III, Fig. 8), Lenticulina sp. (Pl. III, Fig. 14), Mohlerina basiliensis (MOHLER) (P1. III, Fig. 11), ?Mohlerina sp., Nautiloculina broennimanni ARNAUD-VANNEAU \& PEYBERNES (P1. III, Fig. 10), Labyrinthina mirabilis WEYNSCHENK (P1. III, Fig. 12), Lituola? cf. baculiformis SCHLAGINTWEIT \& GAWLICK, Protopeneroplis striata WEYNSCHENK (P1. III, Fig. 15), Protopeneroplis sp., Reophax? rhaxelloides SCHLAGINTWEIT, AUER \& GAWLICK, Troglotella incrustans WERNLI \& FOOKES.

\section{Incertae sedis encrusters}

Bacinella irregularis RADOIČIĆ, Crescentiella morronensis CRESCENTI, Iberopora bodeuri GRANIER, Koskinobulina socialis CHERCHI \& SCHROEDER, Labes atramentosa ELIÁŠOVÁ, Lithocodium aggregatum ELLIOTT, Radiomura cautica SENOWBARI-DARYAN \& SCHAEFER.

\section{Worm tubes}

Terebella lapilloides MUENSTER, Mercierella dacica DRAGASTAN.

As a whole, the above mentioned association is typical of Oxfordian-Tithonian shallow-water deposits. Among the taxa with stratigraphical significance (dasycladalean algae and benthic foraminifers), only Labyrinthina mirabilis has a relatively narrowly delimited position, being known from the Upper Oxfordian-Kimmeridgian interval, and possibly from the Lower Tithonian (Bassoullet, 1997). All the other algae and foraminifers are known from much wider stratigraphical intervals, ranging from Callovian-Oxfordian up to the Berriasian (Bucur 1999, Granier and Deloffre 1993, for calcareous algae; Loeblich and Tappan 1988, for foraminifers). Since the Oxfordian is represented by radiolarites in the outcrop area of the Braşov Series deposits, it can be concluded that the age of the Mateiaş Limestones is definitely Kimmeridgian; however, their top may also include the Early Tithonian.

Within the Cretaceous conglomerates we found rare specimens of the red algae Parachaetetes asvapatii PIA (Pl. III, Fig. 7) and Paraphyllum primaevum LEMOINE (Pl. III, Fig. 6), indicating an Albian-Cenmanian age.

\section{DISCUSSION}

The four main facies and their associated microfacies developed in distinct environments.

Facies $\mathrm{A}$ and $\mathrm{B}$ characterize the platform margin and the upper part of the platform slope. Facies $\mathrm{C}$ is characteristic of the platform slope, and Facies D characterizes the lower part 
of the slope and the toe of slope. Within Facies A and B (coral-microbial reefs, and reef rudstone), Lithocodium and Bacinella are present but rare among the encrusters, in comparison with Crescentiella, Radiomura and encrusting sclerosponges. This could be taken as evidence that most of the Mateiaş Limestone developed in shelf margin and slope environments. Similar microfacies were documented by Schlagintweit and Gawlick (2008) for Upper Jurassic forereef slope environments on the margins of Neothetyan platforms.

The presence of reef-limestone blocks within the allodapic limestones (turbidites) from the upper part of the succession is difficult to explain based on the available outcrop data. Two interpretations can be considered: (1) the blocks represent reef deposits of the platform margin resedimented in contemporaneous deeper carbonate deposits of the lower slope. Such processes could be the result of relative sea-level change or of syn-tectonic disturbance (e.g., Leinfelder, 1992; Gawlick and Schlagintweit, 2006); (2) the blocks are fragments of reef banks caught within the core of isoclinal folds together with turbiditic deposits generated by major post-depositional tectonic events during the Middle Cretaceous.

Ştefănescu and Ştefănescu (1985) have shown that the thickness of the Mateiaş Limestone decreases eastwards (more precisely from NW to SE) (Fig. 1). They suggested that this indicates the presence of a more elevated area to the east that determined the formation of these deposits on a ramp located along the western flank of Leaota Massif. In our opinion, one has to take into account, when interpreting the depositional model of the Mateiaş Limestone the general framework for the formation of these deposits, especially their genetic relationship with the limestones from the Dâmbovicioara-Piatra Craiului region. When considering these aspects, the Mateiaş Limestone is more likely to have been the result of processes related to the shelf margin and the slope of a larger carbonate platform that occupied the area during the Kimmeridgian-Tithonian interval.

When considering the Mateiaş Limestone in the assembly of the Jurassic limestones from the Braşov Series, it corresponds to its lower-middle part. In the Piatra Craiului Mountains, the lower part of the succession consists of reef slope limestones and coral-microbialite reef limestones. These are followed by bedded limestones locally containg silica nodules, while in some areas (e.g., Prăpăstiile Zărneştilor) these limestones are thin-bedded (centimetricto decimetric layers) and intraformationally-folded, similarly to the allodapic limestones (turbidites) from the upper part of the succession in the Hulei-Mateiaş area. The upper part of the section in Piatra Craiului consists of shallow water deposits of the inner platform, while in the Hulei-Mateiaş area such deposits are missing.

\section{CONCLUSIONS}

The calcareous succession within the Mateiaş Limestone is mainly represented by coral-microbial limestones associated with hemipelagic limestones and deposits that resulted from gravitational processes (grain flows). This association of gravitational flow deposits with hemipelagic limestones and bioconstructions suggests a fore-reef slope environment.
The vertical evolution of these deposits points to a gradual transition from shelf margin conditions (reef slope in the proximal-median parts of the shelf crest, with mass flows associated with coral-microbial bioconstructions), to shelf slope and slope base (grain flows interlayered with hemipelagites). This evolutionary trend characterizes the south-eastern extremity of the Getic platform in an area where older (Oxfordian, and probably basal Kimmeridgian), as well as younger, Upper Tithonian deposits are missing, as opposed to the more internal areas of development of the Braşov Series (Dâmboviciara, Piatra Craiului) where Jurassic deposits show a complete succession, from Bajocian to Upper Tithonian-Berriasian.

Acknowledgements. We thank the two reviewers (Boguslaw Kolodziej and Stephen Kershaw) for their remarks and suggestions. Thanks are also due to Dana Pop for a first English version, and to Robert Riding for English corrections.

\section{R E F E R E N C E S}

Balintoni, I. 1997, Geotectonics of the metamorphic terrains in Romania. Ed. Carpatica, Cluj Napoca, 176 p. (in Romanian).

Bassoullet, J.P. 1997, Foraminifères. Les grands foraminifères. In Biostratigraphie du Jurassique OuestEuropéen et Méditerranéen (Cariou, E., Hantzpergue, P., Eds.), Bulletin du Centre de Recherche Elf Exploration Production, Mémoire, 17: 293-304.

Bucur, I.I. 1999, Stratigraphic significance of some skeletal algae (Dasycladales, caulerpales) of the Phanerozoic. In Depositional Episodes and Bioevents (Farinacci, A., Lord, A.R., Eds.), Palaeopelagos Special Publication, 2: 53-104.

Eberli, G.P. 1991, Calcareous turbibites and their relationship to sea-level fluctuation and tectonism. In Cycles and events in stratigraphy (Einsele, G., Ricken, W. \& Seilacher, A., Eds.), Springer-Verlag, Berlin, p. 340-359.

Einsele, G. 1991, Submarine mass flow deposits and turbidites. In Cycles and events in stratigraphy (Einsele, G., Ricken, W. \& Seilacher, A., Eds.), Springer-Verlag, Berlin, p. 313-339.

Gawlick, H.J., Schlagintweit, F. 2006, Berriasian drowning of the Plassen carbonate platform at the type-locality and its bearing on the early Eoalpine orogenic dynamics in the Northern Calcareous Alps (Austria). International Journal of Earth Sciences, 95: 451-462.

Granier, B., Deloffre, R. 1993, Inventaire critique des algues dasycladales fossiles. IIe partie - les algues dasycladales du Jurassique et du Crétacé. Revue de Paléobiologie, 14 (1): 19-65.

Leinfelder, R.R. 1992, A Modern-Type Kimmeridgian Reef (Ota Limestone, Portugal): Implications for Jurassic Reef Models. Facies, 26: 11-34.

Loeblich, A.R, Tappan, H. 1988, Foraminiferal genera and their classification. Van Nostrand Reinhold, New York, $970 \mathrm{p}$.

Patrulius, D., Ghenea, C., Ghenea, A. \& Gherasi, N. 1968, Geological map of Romania scale 1:200.000, Târgovişte Sheet \& Explanatory note. Comitetul de Stat al Geologiei, Institutul Geologic. 
Patrulius, D. 1969, The geology of Bucegi Massif and Dâmbovicioara Couloir. Ed. Academiei R.S.R., Bucureşti, 321 p. (in Romanian).

Popescu-Voiteşti, I. 1909, Contributions to the geological and paleontological study of the hills between Dâmbovița and Olt rivers. Buletinul Geologic, II (3): 207-280 (in Romanian).

Săndulescu, M. 1984, Romanian's geotectonics. Ed. Tehnică, București, 336 p. (in Romanian).

Schlagintweit, F., Gawlick, H.J. 2008, The occurrence and role of microencruster frameworks in Late Jurassic to Early Cretaceous platform margin deposits of the Northern Calcareous Alps (Austria). Facies, 54 (2): $207-$ 231.
Ştefănescu, M., Ghenea, C., Dimitrescu R., Mihăilescu N., Dincă L., Gheuca I., Mărunţeanu M., Ghenea A., Ştefănescu Maria, Andreescu I. \& Mihăilă, N. 1983, Geological map of Romania, scale 1:50.000, Câmpulung Muşcel Sheet. Institutul de Geologie şi Geofizică, Bucureşti.

Ştefănescu, M., Ş tefănescu, Maria 1985, Stratimetry and structure of the Mateiaş Limestone. Dări de Seamă ale Institutului de Geologie şi Geofizică LXIX (5): 109-115. 

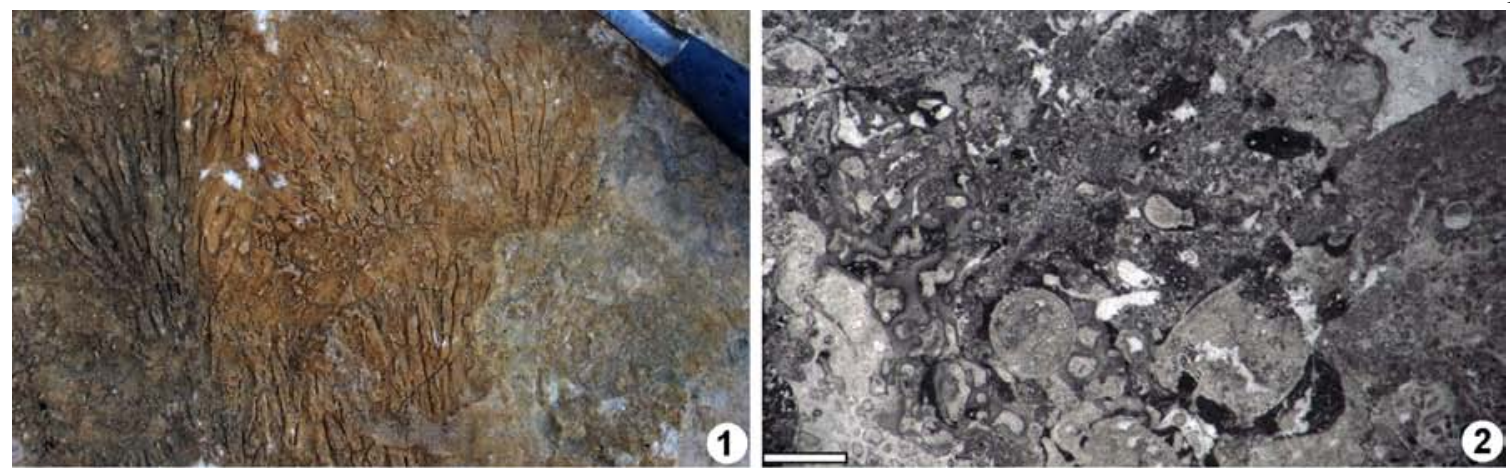

PLATE I
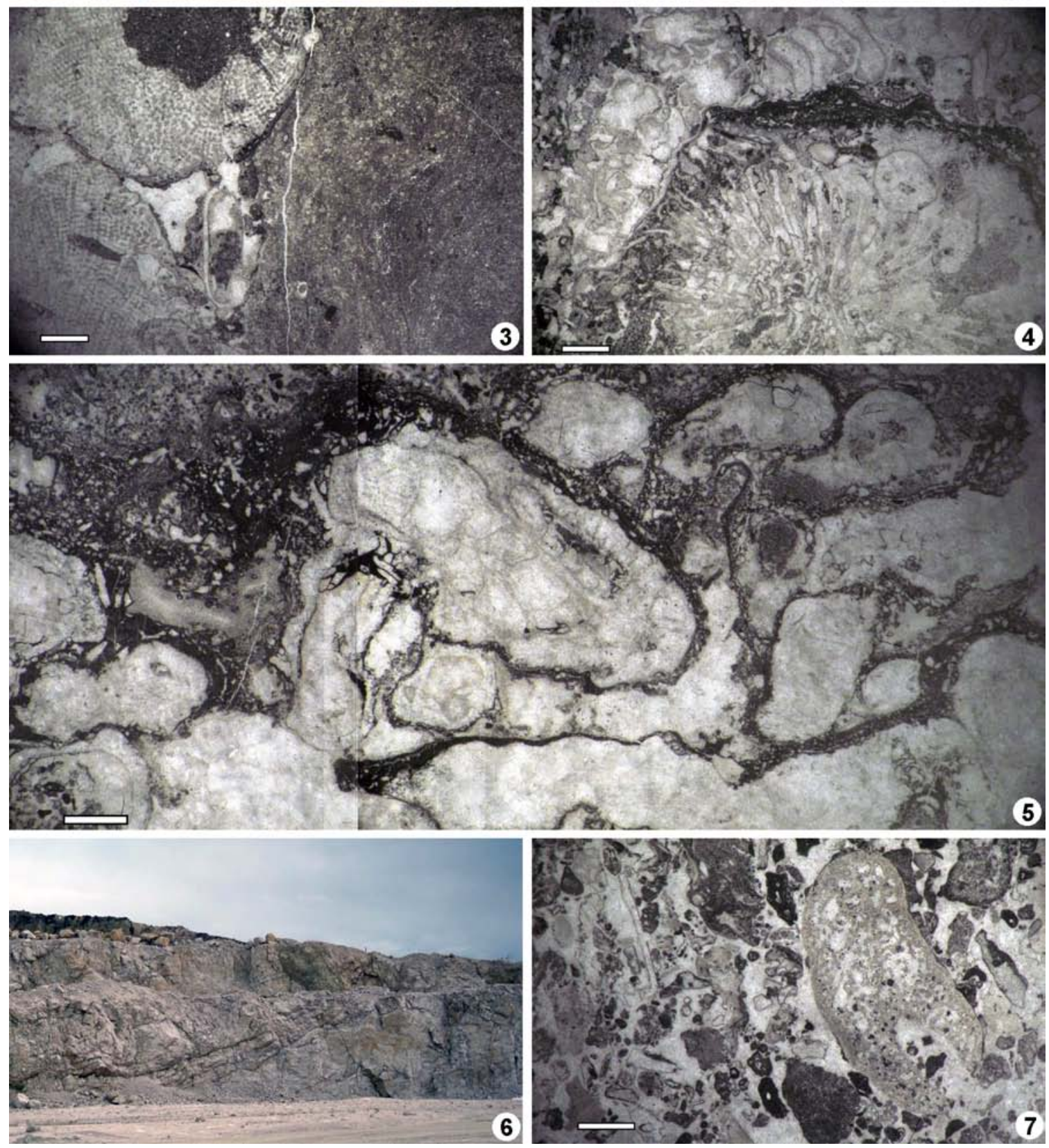

Plate 1. Facies and microfacies (Age: Kimmeridgian-Lower Tithonian; scale-bar in Figs. $2-5$ and 7 is 2 mm).

Fig. 1. Coral limestones. Corals are revealed by surface weathering (Hulei Quarry).

Fig. 2. Peloidal microbialites associated with encrusting organisms such as Radiomura and Crescentiella. Sample 10802 (Hulei Quarry).

Figs. 3-5. Coral-microbial boundstone. The microbialites commonly developed on the coral framework, either as stromatolitic-thrombolitic crusts or as Bacinella-Lithocodium crusts, sometimes associated with encrusting foraminifers or cyanobacterial crusts. 3: sample 10834 (Hulei Quarry); 4: sample 10928 (Hulei Quarry); 5: sample M-43 (Hulei Quarry).

Fig. 6. Grain flows on the coral-microbial reefs and reef rudstones, and intercalated with the final ones (Hulei Quarry).

Fig. 7. Bioclastic-intraclastic rudstone. The larger fragments are bioclasts, mainly corals but also microbialites. Sponges are occasionally present as well as large breccia intraclasts. Sample 10919 (Hulei Quarry). 

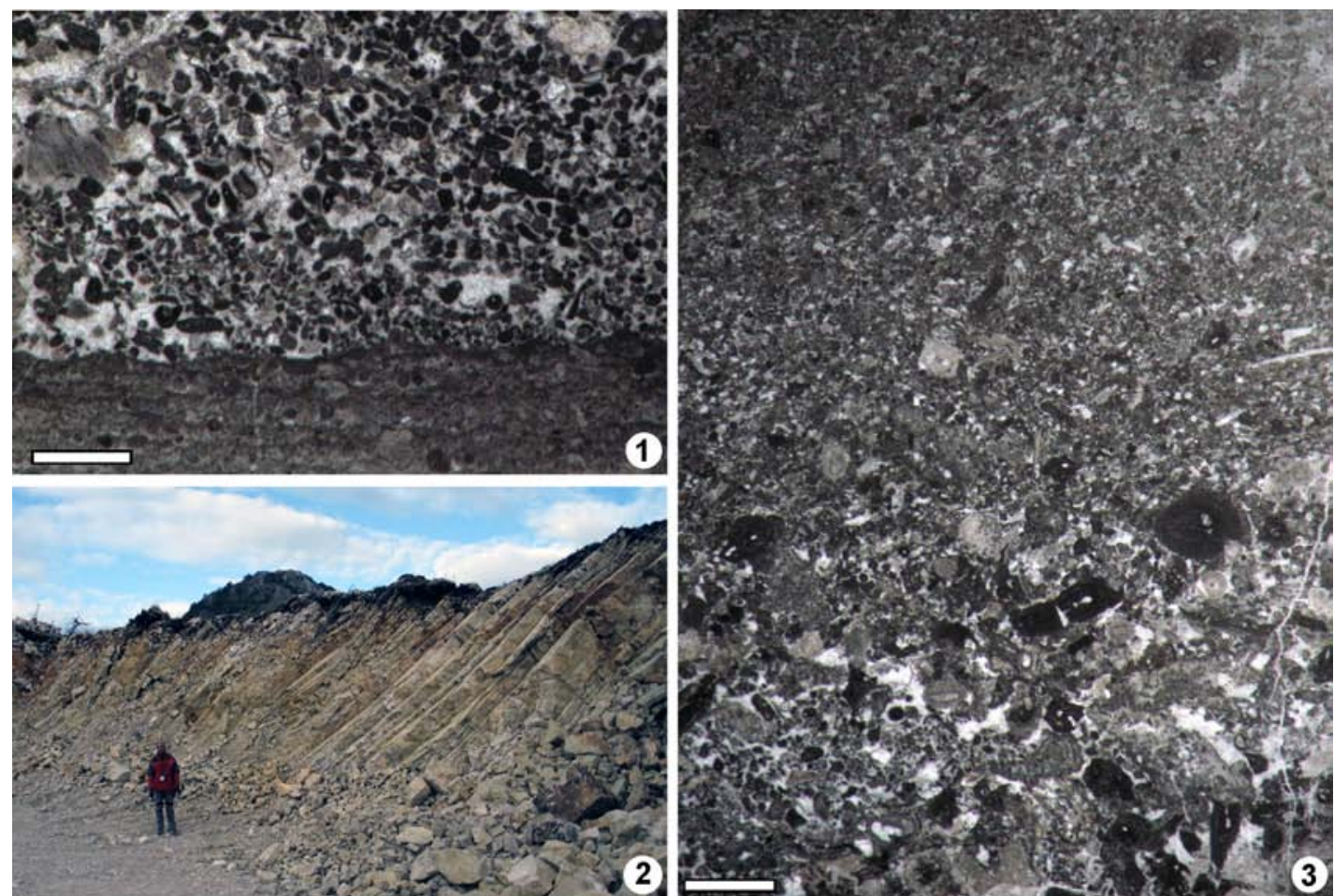

PLATE II
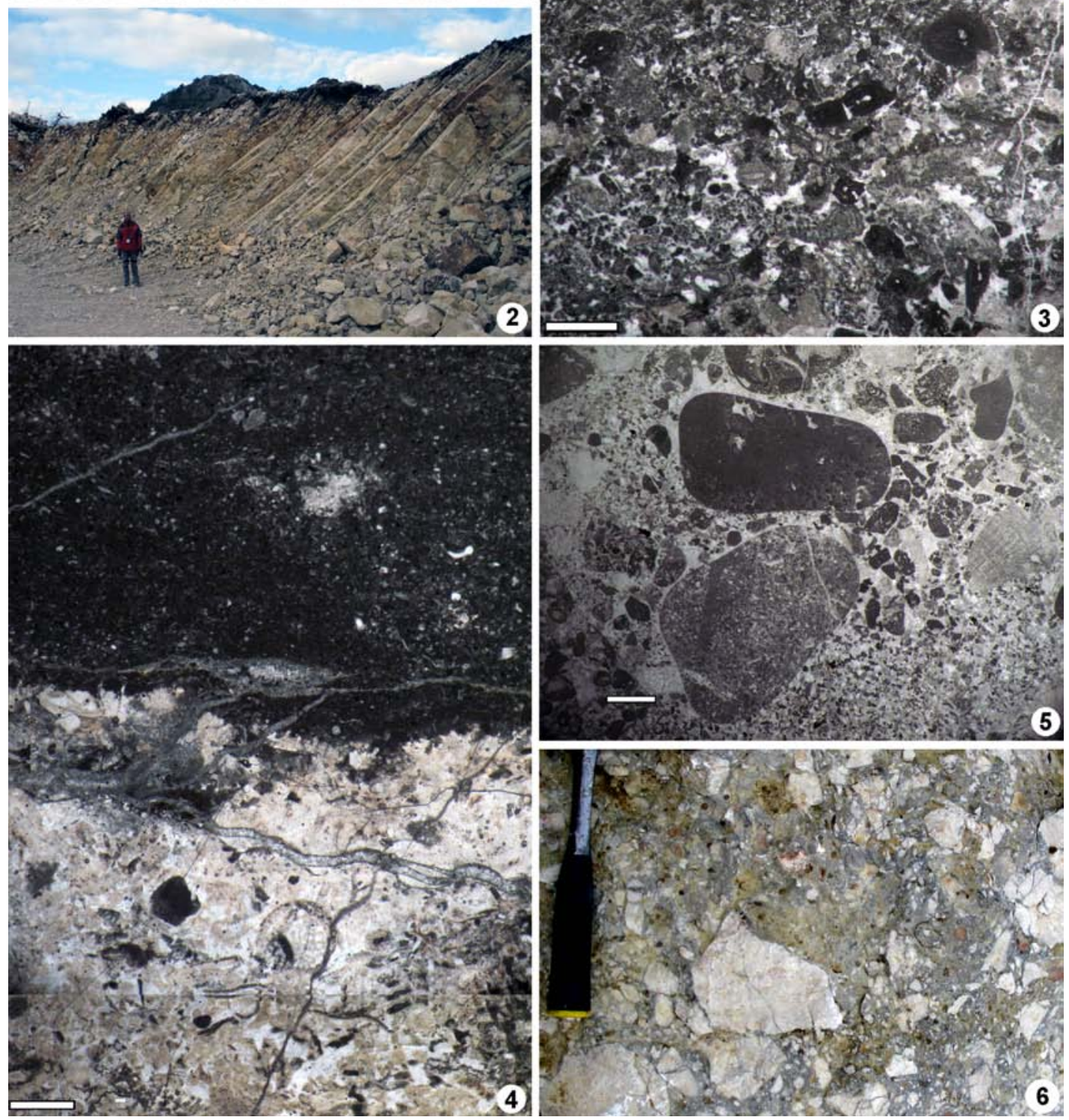

Plate 2. Microfacies (Ages: 1-4, 6: Kimmeridgian-Lower Tithonian; 5: Albian-Cenomanian; scale-bar in Figs. 1 and 3 to 6 is 2 mm).

Fig. 1. Allodapic grainstone; sometimes directly overlying coral-microbial boundstones or microbial crusts that stabilized the former sediment. Sample 10972 (Hulei Quarry).

Fig. 2. Allodapic limestones (calcareous turbidites). Thin-bedded turbidites, sometimes with cherts, centimetre to decimetre in thickness, developed on the tops of the grain flows (Hulei Quarry).

Figs. 3, 4. Fine-grained turbidites, represented by grainstone and packstone. Small bioclasts are represented mainly by echinoderm debris, frequently with syntaxial overgrowths. Sponge spicules are sometimes frequent. Note the tendency for normal grading (fining upwards). The cherts, which are present at some levels, are diagenetic; 3: sample 11015 (Hulei Quarry); 4: sample C-3 (Mateiaş Hill).

Fig. 5. Microconglomerates. Rounded calcareous pebbles of very diverse origins (from shallow water intertidal or shallow subtidal limestones to fine-grained lime turbidites). Fragments of crystalline schist are also present. The matrix is carbonate, silt to fine-sand, sometimes with frequent quartz grains. Sample BR1A (Mateiaş Hill).

Fig. 6. Breccia with limestone fragments, and reddish-brown to grey matrix, predominantly carbonate silt with very rare quartz grains. Probably karstic breccias (Hulei Quarry).

Studia UBB, Geologia, 2010, 55 (2), 33 - 41 

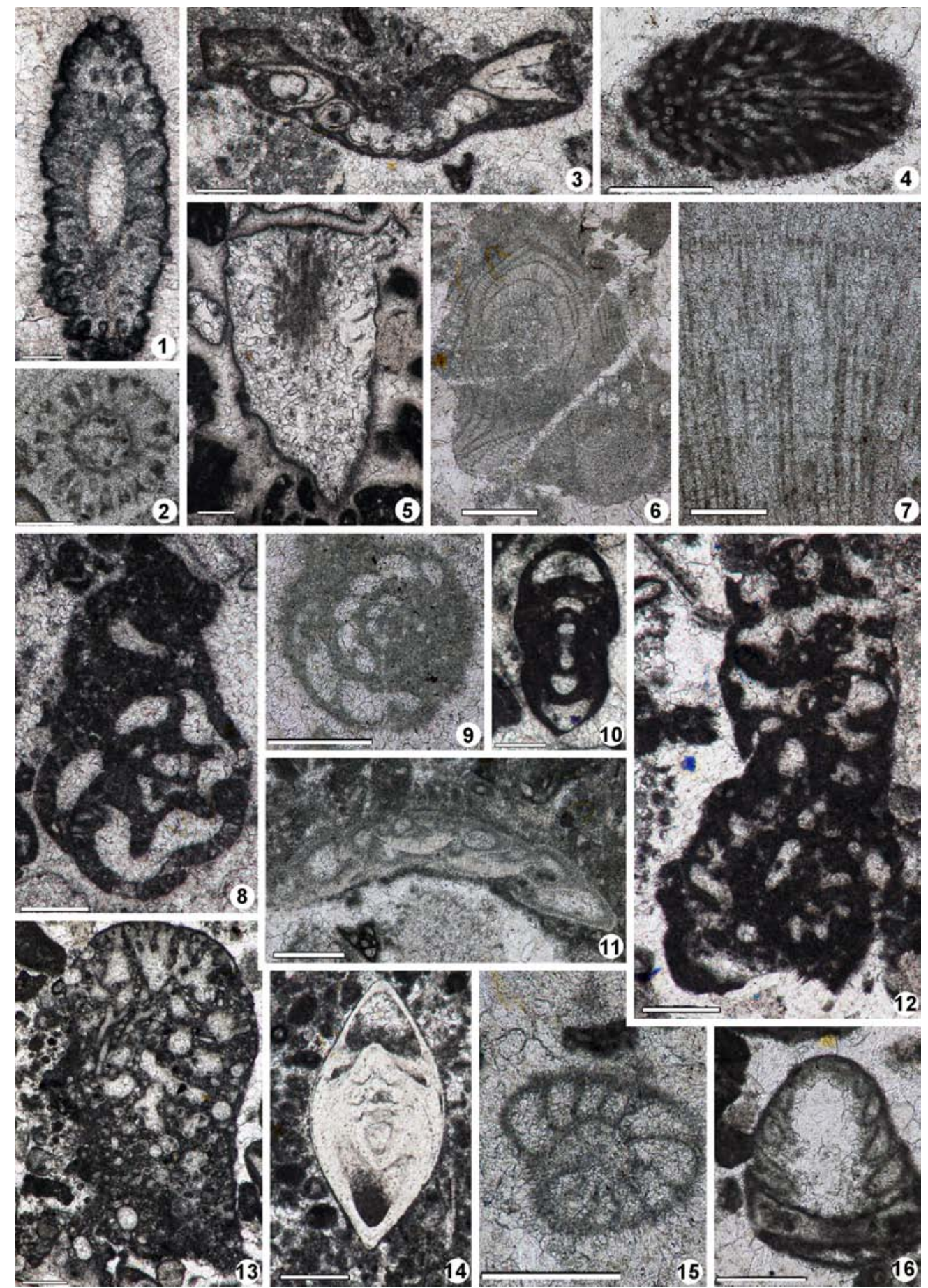

Plate 3. Microfossils (Ages: 1-5, 8-16: Kimmeridgian-Lower Tithonian; 6, 7: Albian-Cenomanian; scale-bar is $0.25 \mathrm{~mm}$ ).

Figs. 1, 2. Dasycladalean calcareous algae: Salpingoporella pygmaea (GUEMBEL). 1: sample 10985 (Hulei Quarry); 2: sample 10904 (Hulei Quarry).

Fig. 3. Clypeina sulcata (ALTH). Sample 10818 (Hulei Quarry).

Fig. 4. Halimeda misiki SCHLAGINTWEIT, DRAGASTAN \& GAWLICK. Sample M-27 (Mateiaş Hill).

Fig. 5. Arabicodium sp. Sample 10862 (Hulei Quarry).

Fig. 6. Paraphyllum primaevym LEMOINE. Sample F6-m27.3 (Mateiaş Hill).

Fig. 7. Parachaetetes asvapatii PIA. Sample BR1A (Mateiaş Hill).

Fig. 8. Everticyclammina virguliana (KOECHLIN). Sample 10867 (Hulei Quarry).

Fig. 9. Charentia evoluta (GORBATCHIK). Sample 10839 (Hulei Quarry).

Fig. 10. Nautiloculina broennimanni ARNAUD-VANNEAU \& PEYBERNÈS. Sample 2540 (Mateiaş Hill).

Fig. 11. Mohlerina basiliensis (MOHLER). Sample11010 (Hulei Quarry).

Fig. 12. Labyrinthina mirabilis WEYNSCHENK. Sample 2552-S (Mateiaş Hill).

Fig. 13. Coscinophragma cribrosa (REUSS). Sample 11059 (Hulei Quarry).

Fig. 14. Lenticulina sp. Sample 11000 (Hulei Quarry).

Fig. 15. Protopeneroplis striata WEYNSCHENK. Sample 10951 (Hulei Quarry).

Fig. 16. Andersenolina alpina (LEUPOLD). Sample 11003 (Hulei Quarry). 